\title{
LOS MUNDOS DEL TEXTO EN LA PRINCESA Y EL GRANUJA DE PÉREZ GALDÓS (TEORÍA Y PRÁCTICA)
}

\author{
Josefina Albert Galera
}

Universidad de Tarragona

\section{INTRODUCCIÓN}

Todo texto se muestra como un objeto semiótico, que debe ser sometido a una dinámica capaz de generar el sentido (Coseriu, 1978: 128-147). . Las condiciones que debe cumplir vienen reguladas por la semiótica ${ }^{1}$, que es la que se ocupa de los signos lingüísticos (Bobes Naves, 1973), y que tiene sus raíces en la filosofía griega (Sémeiétike). Esta ciencia de la comunicación, es decir, de la transmisión de información (Malmberg, 1977 [1973]: 9), deberá dar cuenta de las condiciones de la aprehensión y

1 Término usado por Peirce y Morris y adoptado por la carta constitutiva de la International Association for Semiotic Studies, en 1969. Recuérdese que Saussure la denomina "Semiología», una ciencia que estudie la vida de los signos en el seno de la vida social, de la que lingüística no es más que una parte (Saussure, 1976: 60). 
de la producción de sentido, entendido este término como «el particular contenido lingüístico que, en un determinado acto de hablar (o en un «texto»), se expresa por medio de la designación (referencia extralingüística como tal) y del significado (contenido dado en cada caso por la lengua empleada en el acto de hablar) y más allá de la designación y del significado como tales», es decir, el sentido (Coseriu, 1977: 247) ${ }^{2}$.

El signo, que es el vehículo comunicativo, establece diversos tipos de relaciones. Si éstas se producen en el sistema y en el proceso (Hjelmslev, 1974 [1943]), comportan el doble juego de la sintagmática y la paradigmática. Son relaciones intrasígnicas, que se constituyen en Sintaxis Lingüística.

La idea de signo como portador de información implica otro tipo de relaciones, las de signo-referente, que da lugar al estudio de la Semántica.

El tercero de los componentes, la Pragmática. que es la base de los otros dos, va orientado a suscitar una reacción en el receptor, pero también tiene que ver con el emisor como sujeto productor de una comunicación que, de alguna manera, queda mediatizada por él mismo. Se trata de las relaciones del signo con los «intervinientes» en la comunicación y con el contexto (Kristeva, 1978: 27).

\section{CONDICIONES DE LA SEMIÓTICA LINGÜÍSTICA}

1.1. La Semiótica Lingüística en su actividad, si se me permite el término, investigadora de los textos de lengua natural pondrá al descubierto los sistemas de codificación que operan en ellos (Albert, 1988: 54). Los textos objeto de estudio deberán cumplir, por tanto, algunas condiciones, como es poner de manifiesto «las propiedades de cohesión y coherencia, relacionadas pero distintas» (Lyons, 1983 [1981]: 200). Por ejemplo, cuando se construye un texto se practican una serie de recursos, como es la elipsis y el uso de pronombres, así como la presencia de determinadas partículas de conexión. De esta forma, la frase: «Estoy esperando a que den las 7,30 para ir a buscar al niño. Cuando

2 A este respecto Coseriu (1977: 248) dice que «Una oración como Sócrates es mortal tiene desde el punto de vista de la lengua española sólo un significado; su sentido, en cambio, puede ser completamente diferente según el texto en que la oración misma aparezca (por ejemplo, según si se presente en un silogismo, en un poema o en un acto de comunicación práctica, en una situación de la vida diaria, etc.)». También Guiraud (1976: 28-29). 
venga a casa, lo bañaré, le daré de cenar y lo acostaré», sería un texto que cumple las condiciones de cohesión, cosa que no sucedería si en lugar de la segunda frase dijera: * «traeré el niño a casa, bañaré al niño, daré de cenar al niño, acostaré al niño» (Albert, 1992: 536).

1.2. Un texto guarda coherencia cuando lo que se dice en cualquier unidad del texto es relevante para lo que se acaba de decir. La «desconexión» se produce cuando la expresión de un pensamiento se «descuelga» de todo lo anterior produciendo una especie de perplejidad en el lector. La frase «Esto no tiene sentido» sería adecuada para calificar el contenido de dicha expresión, cuando no puede solucionarse, por ejemplo, mediante el conocimiento acumulado del hablante y del oyente.

De lo anterior se deduce que las palabras que componen un texto no van simplemente una tras otra en la sucesión discrecional de un diccionario, sino que forman estructuras de acuerdo con determinadas leyes lingüísticas. Éstas conforman la textualidad del texto y determinan que el lector, no sólo reciba una confusa sucesión de palabras diferentes, sino indicaciones de tal naturaleza que pueden ensamblarse en una instrucción global relevante para su comportamiento. Si el lector después de la lectura ha captado adecuadamente las indicaciones del autor y piensa o reflexiona de distinta manera sobre lo que allí se expresa, es que ha entendido el significado del texto (Weinrich, 1981 [1976]: 18-19).

\section{LAS RELACIONES EXTRASÍGNICAS}

Si bien es cierto que los signos se dan cotexto unos a otros (Petöfi, 1975: 1, 10), sin embargo, para un estudio completo del texto lingüístico deben intervenir otros parámetros, en cuyo derredor (contexto) se organiza la producción significante. Según Morris (1958 [1938] y (1962 [1946] $)^{3}$ es necesario establecer otro tipo de relaciones complementarias de los signos lingüísticos con otras realidades las extrasígnicas, lo que ha llevado a algunos autores a afirmar que en un estudio textual hay que introducir un esquema de tres partes, en el que tenga cabida el referente.

2.1. Así, por ejemplo, Lyons (1975 3 [1968]: 418) habla de la necesidad de presentar un término moderno para las «cosas» en la medida

3 El esquema de Morris ha sido aplicado en Albert Galera (1987); así como a algunos textos literarios desde la Pragmática en diferentes artículos míos (Albert Galera, 1988, 1992). 
en que son «nombradas» o «significadas» por las palabras. La relación que se mantiene entre las palabras y las cosas - añade - es una relación de referencia. Lo representa mediante el denominado «triángulo semiótico»:

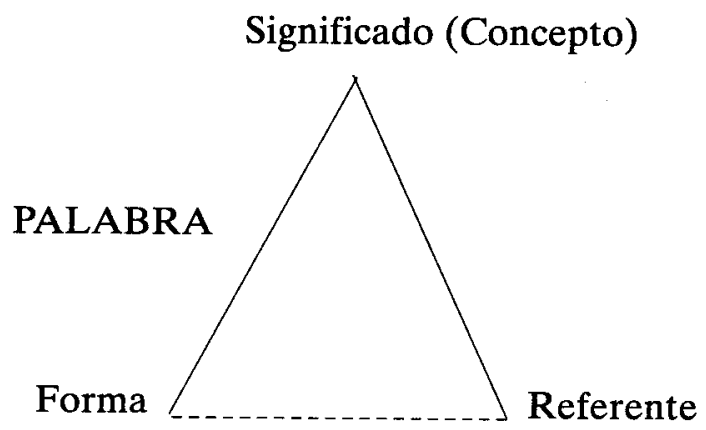

Obsérvese la línea discontinua que relaciona indirectamente la forma con el referente; la relación directa y mediata se establece a través del significado.

El diagrama de Lyons se adecua a la concepción tradicional del significado que, en el plano textual, incluye dos de los tres niveles de estudio del esquema de Morris, es decir, la Sintaxis y la Semántica. A través del término mundo, posteriormente (Lyons, 1983 [1981]), incorporará la Pragmática.

2.2. János S. Petöfi (1975: 87) utiliza los términos de Frege y los de intensión y extensión de Carnap para modificar el triángulo semiótico de Lyons. Su triángulo de la significación, válido para el tratamiento de textos de lengua natural, introduce dos tipos de relaciones: las semántico-intensionales y las semántico-extensionales. Podría esquematizarse de la siguiente manera:

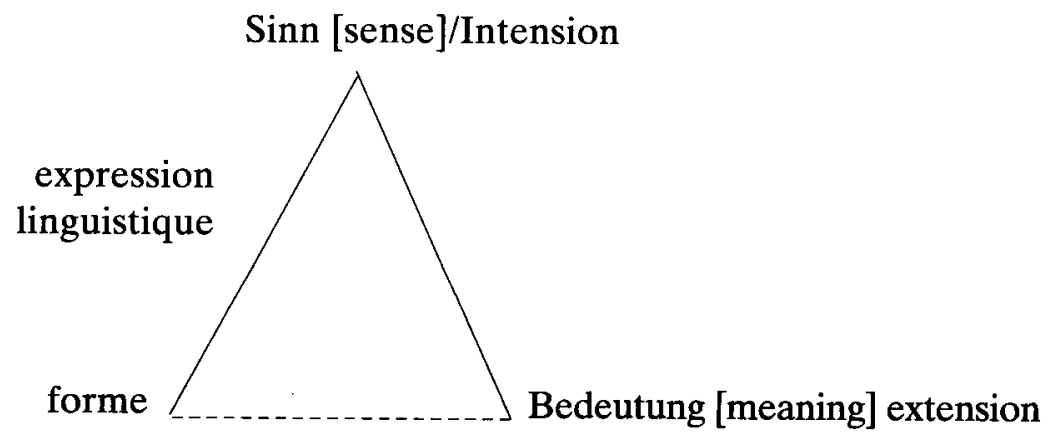


En el texto de lengua natural, según Petöfi, hay que distinguir dos niveles: uno profundo o de base y otro superficial. Éste es el textomanifestación o conjunto ordenado de oraciones sometidas a una dinámica interna que da coherencia a esa manifestación. El segundo nivel es el de la estructura profunda como realidad de un plan global subyacente, cuyo entramado sostiene el texto-manifestación. La estructura profunda es la que engendra la significación del texto en superficie. En este sentido, el texto es el conjunto de todas las informaciones subyacentes a un discurso, que manifiesta coherencia, sentido y completez. Es, por tanto, «el constructo teórico que hay detrás de un discurso» (Albaladejo-García Berrio, 1983: 223; Albaladejo, 1986: 68). Ese nivel abstracto del funcionamiento lingüístico desembocará en el textomanifestación («genotexto» y «fenotexto», respectivamente, en palabras de Julia Kristeva, 1978: 100).

\section{INTENSIÓN Y EXTENSIÓN}

3.1. De la investigación de la intensión se ocupa la semiótica intensional; su objeto es el estudio de las relaciones intersígnicas e intrasígnicas. Este nivel conviene al cotexto o dominio de los aspectos cotextuales; funciona con sus propias informaciones internas, es decir, las expresadas a través del texto, situándonos así en el nivel superficial de las palabras dichas o escritas. El texto considerado de esta manera contiene -y manifiesta también- un complejo de mundos (posibles) encerrados en los propios signos lingüísticos.

Todo mensaje, toda comunicación textual, presenta una cantidad de información que lleva al lector/oyente de un estado de información más bajo a otro más elevado. Se trata de una progresión temática del texto conocida como tema-rema (tópico-comento) (Weinrich, 1981 [1976]: 175), que permite al receptor, en el proceso de descodificación, crear expectativas que, a su vez, facilitan y aceleran la descodificación. La continuidad discursiva - como bien señala Albaladejo (1986: 128)—, se da precisamente por el surgimiento de mundos y submundos, por la desaparición de unos y por la integración de otros: unos submundos se desvinculan de otros, y, en ocasiones, se produce un intercambio entre ellos.

Los mundos construidos por la semántica, formados a su vez por el sistema de mundos de los distintos personajes, serán activados depen- 
diendo de la semiótica extensional (léase pragmática). Su análisis permite evidenciar la organización subyacente del texto (Albaladejo, 1986: 124).

3.2. La semiótica extensional, por su parte, se encarga de estudiar el nivel del referente con todas sus circunstancias. Tiene que ver con los aspectos de interpretación semántica extensional y con la producción y la recepción del texto. La extensión textual se configura lingüísticamente y produce como resultado la intensión textual. Alcanza, además, no sólo a los interlocutores en el proceso comunicativo, sino también a la situación, pues ésta forma parte de las condiciones de producción y recepción del texto (Weinrich, 1981 [1976]: 434), lo que nos permite hablar de su dimensión pragmática (Petöfi, 1975: 8-9).

\section{LOS MUNDOS DEL TEXTO}

En el punto anterior decíamos que todo texto manifiesta un complejo de mundos ${ }^{4}$, que están situados en el espacio extensional relativo al mismo. Desde un punto de vista teórico-lingüístico y teórico-literario nos interesa la descripción del mundo que es expresado lingüísticamente en texto de lengua común o en texto literario (Albaladejo, 1986: 56-57). Quiere ello decir que las expresiones de lengua natural están ligadas a los estados de cosas en lugar de a la 'verdad' o 'no verdad' habituales; no solamente se puede hablar de las circunstancias de la realidad «real», sino de otras «realidades» imaginarias, que pueden expresarse como sigue: «Soñé que me transformaba en escarabajo». En la realidad del sueño existe el hecho de «transformarse en escarabajo». Esto es lo que se llama una realidad alternativa, frente a la realidad actual. Ambas realidades poseen un término común que las designa: mundo (posible). Semejante mundo hay que considerarlo como una abstracción, como algo construido por la semántica que lo obtiene enlazando las unidades abstractas de la lengua con las unidades abstractas de la realidad, a través de los significados conceptuales de las unidades de la lengua.

4 Un mundo es una colección de circunstancias. Éstas se componen de objetos con determinados caracteres y relaciones mutuas. También un mundo es un conjunto de seres, localizados en el espacio-tiempo y envueltos, singular o conjuntamente, en distintas situaciones estáticas o dinámicas (Lyons, 1975 [1968]: 165). Vid. también Albadalejo (1986: 124) donde dice: «El sistema de mundos del texto narrativo está constituido por los mundos de los distintos personajes». Vid. además, Van Dijk (1983: 38-39). 
4.1. Los mundos del texto están formados por los mundos de los diferentes personajes y acontecimientos que tienen lugar en el tejido lingüístico del texto. De ahí que se deba hablar de un mundo global, que es la estructura de conjunto referencial, y el mundo o los mundos particulares de cada uno de los personajes. A la vez, en cada mundo de personaje puede haber varios submundos, establecidos por medio de las actitudes, acciones, descripciones, etc., y cuyas articulaciones producen una estructura de sentido propia de cada personaje. Estos mundos se encuentran jerarquizados con respecto al mundo o mundos de otros personajes. Muchas situaciones que se le plantean a un personaje permiten acceder a otras situaciones del mismo personaje o de otros con los que se relaciona. Ello se debe al dinamismo que preside todo el relato. Normalmente expresamos este fenómeno diciendo que el mundo está cambiando constantemente de un estado a otro. Aparecen unos mundos y desaparecen otros, o bien se integran o complementan entre sí. Este proceso, que da paso al concepto de accesibilidad, convierte el mundo real en un mundo posible, existente sólo en el pasado, y crea, al mismo tiempo, expectativas de mundos posibles en el futuro. Como bien nos recuerda Lyons (1983 [1981]: 165), cada lengua natural está capacitada para proporcionar a los individuos los medios apropiados para identificar el mundo que es real en un momento dado y distinguirlo de los demás mundos.

4.2. Para la interpretación del texto el receptor tiene que establecer un modelo de mundo coincidente con el del productor en su proceso de elaboración textual, es decir, que productor y receptor han de participar del mismo código semántico extensional (Albaladejo, 1986: 63). El modo cómo se relacionan los textos depende también de nuestro conocimiento sobre el respectivo conjunto de mundos y de sus postulados básicos (Van Dijk, 1983 [1978]: 49). Ello implica que el acceso de un mundo a otro debe ser adecuado al marco o contexto pragmático actual en el que un hablante comunica algo. Como es bien sabido los marcos forman parte de nuestra memoria semántica general: son determinadas formas de organización del conocimiento convencionalmente establecido que poseemos del 'mundo'. El conocimiento del marco es necesario para la interpretación correcta de los más diversos sucesos sociales. Para Umberto Eco (1986 ${ }^{3}$ [1968]: 74) el patrimonio del saber de un comunicante es el que permite al destinatario elaborar las valoraciones y las selecciones correspondientes para establecer el sentido del texto. El marco es también el que permite hacer determinadas deducciones que se reconocen como actos semióticos (Van Dijk, 1983 [1978]: 185). 
No es menos cierto, por otra parte, que el hablante construye la estructura textual también sobre la base de sus propios intereses, prejuicios, conocimientos, e incluso de sus deseos. Ello quiere decir que las situaciones cognitivas del propio hablante influyen en la manera cómo se extraen y reelaboran las informaciones de un texto. Un mayor conocimiento sobre el tema lleva a una comprensión más rápida (Van Dijk, 1983 [1978]: 208 ss.). Por ejemplo, en el cuento La princesa y el granuja de Galdós, el conocimiento por parte del lector del marco mundo de la fantasía, explica la presencia de elementos inconcebibles en la realidad extralingüística, como es el que una figura de barro se mueva, y hable, y se enamore.

\section{EL CUENTO LA PRINCESA Y EL GRANUJA}

Al iniciar la lectura del relato de Pérez Galdós nos encontramos con el personaje central, Pacorrito Migajas, en torno al cual giran todos los demás personajes y sucesos que se dan cita en el cuento. Además de Pacorrito, aparece la dama, que ni siquiera tiene nombre propio y de la que Migajas está perdidamente enamorado, los compradores de la figura de barro, la familia de Migajas, cuya única función es la de aclarar algunas circunstancias y coadyuvar así también al sentido global del texto, y los criados, que no dejan entrar a Pacorrito en el palacio, cuando éste aparece para rescatar a la señora de sus sueños. Todos ellos cumplen una única función: permitir que avance la narración.

El mundo de Pacorrito Migajas puede ser desdoblado en los submundos siguientes:

Mundo real efectivo ${ }^{5}$, que a su vez está formado por fragmentos ensamblados que nos los devuelven como personaje: su propia existencia, la esfera de sus operaciones mercantiles, el submundo de su realidad física y social, las aventuras que protagoniza en el palacio y su posterior huida.

a) El submundo de la realidad y personal y social. Pacorrito es un muchacho, que «apenas pasaba de los siete años» $(79,1)$, harapiento,

5 Lo real efectivo, aunque lleve dentro de sí un ente inexistente, que es la ficción de la que trata, en sí mismo tiene existencia, real, objetivable. En este caso es el tejido lingüístico, plasmado en signos, que «cuenta» la ficción de Pacorrito y sus aventuras. 
«de piel curtida del sol y del aire», vendedor de periódicos, solo en el mundo, pero que «enfrentó la situación como un héroe» $(80,1)$. Su condición de pobreza y desamparo total lo enajena, creando en alrededor suyo todo un mundo de fantasía, en el que las emociones jugarán un papel fundamental en el comportamiento y decisiones posteriores.

b) El submundo imaginado, en el que la fantasía juega un papel decisivo en el desarrollo de la trama. Migajas cree que ella, la dama representada por la figurilla de barro, corresponde a su amor como si se tratara de un ser humano. Ella, relata el narrador, «decíale mil cosas deleitables» $(81,2)$ y hasta le pide que la salve.

c) Submundo de los sentimientos, debidos a su enamoramiento. También pertenecen a este mundo todas las sensaciones, un tanto "peregrinas», como se indica en el texto, cuando se convierte, al final del relato, en un muñeco más del escaparate.

d) El submundo soñado ( Pero como estaba tan fatigado, recostó la cabeza sobre el cuerpo de su ídolo y se durmió como un ángel» $(83,2)$ ), que se entrecruza con todos los demás submundos, responde en su contenido, cuando ya poseemos todas las claves interpretativas, a las expectativas generadas en el curso de la lectura. Durante el sueño se desarrollan los sucesos más hermosos y deleitables para Migajas. Precisamente en el submundo soñado, a la felicidad le sigue la consumación del drama de nuestro personaje. Desde aquí - casi de una manera despiadada - el narrador lo reenvía al escaparate, ante el que tantas veces se había parado para dirigir sus requiebros a la princesa de sus sueños. Hasta este preciso momento $-y$ únicamente a través de las lamentaciones del personaje- el lector no se apercibe de que Migajas no era sino un infortunado muñeco más del escaparate.

e) El submundo irónico, clave para la interpretación de muchas expresiones, especialmente en la presentación de personajes.

El engendramiento del sentido (Greimas/Courtés, 1989) se produce a medida que los submundos de Migajas se van sucediendo y complementando. A su vez, cada uno de estos submundos dará paso a otros para permitir que la narración avance y vayan conduciendo al lector hacia el sentido global del cuento.

La frase con la que comienza el relato, «Pacorrito era un gran personaje», creará en el lector unas determinadas expectativas que éste ha ido almacenando en la memoria semántica, como resultado del conocimiento que posee del mundo (el marco), según el cual a cada expresión se le asignan unos contenidos y no otros. Pero al mismo tiempo 
que el lector se adentra en la lectura del texto galdosiano, experimenta una serie de perplejidades al «toparse» con las descripciones que el narrador hace de la situación personal y de la deprimente realidad social en la que se desarrolla la vida del pobre Migajas. La burla fina y disimulada, en el uso del lenguaje que es la ironía, impregna todo el relato. Obsérvese en qué términos se describe al pobre Pacorrito:

- piel curtida

- ojos negros y vividores

- boca fea

- orejas como aventadores

- vestía camisa de todos los colores

- pantalón hecho de remiendos

- guiñapo en el cuello a modo de bufanda

- sin zapatos ni medias [...].

Y ésta otra que se refiere a la actividad que realiza nuestro personaje para sobrevivir: «Vendía fósforos, periódicos y algún billete de lotería, tres ramas mercantiles, que, explotadas con inteligencia, podían asegurarle honradas ganancias» $(8,1)$.

Se trata de expresiones imprevisibles, que quedan «descolgadas» de todo lo anterior ${ }^{6}$, ya que no existe «conformidad» entre expresiones que pertenecen al mismo mundo descrito; es decir, productor y receptor no participan del mismo código semántico extensional. De ahí que, para descodificar correctamente el texto, el lector debe asignar a cada expresión un sentido diferente del que las palabras parecen indicar. El desajuste entre el nivel superficial y el profundo del texto llega al lector como una señal de alerta, que conlleva un mensaje implícito, cuyo sentido no sólo es diferente, sino que es contrario al del mensaje explícitamente manifestado. La relación semiótica de contradicción (Greimas/Courtés, 1989) que surgen en el texto-manifestación recupera su coherencia cuando hace su presencia el submundo de la ironía, modificando de esta manera la expresión «era un gran personaje». La manipulación semántica en el uso del lenguaje que se hace en las descripciones es prueba evidente que éstas dentro del relato no son en absoluto ajenas a la organización y ensamblaje de los mundos del texto. Por el contrario, cumplen una función cardinal, ya que constituyen verda-

6 Cuando un texto nos resulta incomprensible es porque las presuposiciones aparecidas en ese momento no se conforman a la macroestructura; es decir, no aparecen en el marco adecuado ni son sus componentes posibles, lo que las convierte en incompatibles con las expectativas ya construidas. La «rareza» de un texto va estrechamente ligada a la «rareza» de circunstancias posibles en mundos posibles (Dijk, 1983 [1978]: 201). 
deros «nudos» del relato, como si se tratara de unidades narrativas (Barthes, 19743: 30).

Con la expresión «estaba solo en el mundo», se introduce al lector en el conocimiento del entorno familiar de Migajas, cuya primera frase, «la familia de Pacorrito no podía ser más ilustre» $(79,2)$ crea unas expectativas también significativamente diferentes de las esperadas. El submundo de la ironía, siguiendo el mismo procedimiento que en el caso anterior, hace que aparezca un mundo coincidente con el del productor, modificando, automáticamente, las expectativas generadas por el calificativo «ilustre».

El dinamismo de la lectura permite acceder, a través del mundo real efectivo en su esfera de operaciones, al submundo imaginado. Pacorrito se enamora locamente de una figurilla de barro, lo que provoca la aparición del submundo de los sentimientos. El proceso se inicia en el momento en que nuestro personaje se detiene ante el escaparate de un comercio (mundo real efectivo) para contemplar una hermosa figurilla de barro, que provoca en él una fuerte emoción ${ }^{7}$ :

\footnotetext{
«El granuja y ella se miraron. ¡Ay! ¡Cuánto idealismo, cuánta pasión en aquella mirada! Los suspiros sucedieron a los suspiros y las ternezas a las ternezas» $(81,2)^{8}$.

«... cortó el hilo de la dulce comunicación» $(81,2)$.

« ¿Sálvame, Pacorrito mío, sálvame!» $(82,1)$.
}

«La figura tenía abiertos los ojos y miraba con melancólica dulzura a su fiel adorador» $(83,1)$.

El mundo imaginado se articula y se imbrica de esta manera en el real efectivo, creando una atmósfera fantasmagórica, un mundo de fantasía, que provoca unos comportamientos y desencadena una serie de acciones inscritas en el mundo real efectivo. Pacorrito es testigo de la retirada del escaparate de la figurilla de barro:

«... El rapaz miró hacia el interior de la tienda y vio a una de las niñas [...], que sostenía en sus brazos a la dama de los pensamientos de Migajas» (pp. 81-82).

7 «Su cerebro hervía; en su corazón se enroscaban culebras mordedoras; su pensamiento era un volcán; deseaba la muerte; aborrecía la vida; hablaba sin cesar consigo mismo; miraba a la luna; se remontaba al quinto cielo, etc.» $(\mathbf{8 1}, 1)$.

8 Las páginas corresponden a la edición de las obras de $\mathrm{D}$. Benito Pérez Galdós que 
Nuestro conocimiento del marco comercio es el que nos hace comprender que, posiblemente, la figurilla de barro vaya a ser adquirida por los que la sostienen en brazos, como así sucede, en efecto.

Los «horrores de la trata de blancos» $(82,1)$ provocan en él una «violenta emoción» (submundo de los sentimientos), que le llevará a protagonizar una serie de aventuras para recuperar a su amada. "Colgado a la zaga del coche», en el que van los compradores de su amada, recala en el palacio. Esta acción propicia la aparición de otros personajes. Las burlas y vejaciones de que es objeto Migajas por parte del cocinero y criados de palacio se convierten en una auténtica tortura, haciendo de Pacorrito un personaje realmente patético.

La accesibilidad de los fragmentos del submundo del palacio, que, recordemos, pertenece al mundo real efectivo, y al que se le superpone el mundo de la fantasía o mundo imaginado, permiten, a su vez, el acceso al submundo de las decisiones de Migajas: Pacorrito escapa del palacio con la muñeca entre los brazos decidido a «tomar venganza de aquel descomunal agravio» $(83,2)$. Pero en la huida se queda dormido abrazado a la muñeca hecha pedazos. El submundo soñado, que hace su aparición en este momento, se instala de una manera definitiva en la vida de nuestro personaje. Ahora, mientras duerme, Pacorrito protagoniza toda una serie de aventuras maravillosas, que dan respuesta generosa a sus pensamientos depresivos ante la contemplación de la muñeca de barro destrozada. En el sueño todo es nuevo y perfecto; la figurilla de barro se le transforma en princesa esposa. ${ }^{9}$

Es el momento en el que el lector, a partir del patrimonio del saber acumulado en la lectura, junto con las informaciones almacenadas en la memoria, y organizadas mediante un sinfín de textos con los que ha tomado contacto en múltiples situaciones de comunicación (Dijk, 1983 [1978]: 21), elabora las selecciones pertinentes para establecer el sentido global del texto. Para ello hace uso de determinadas estrategias, aplicando una serie de macrorreglas que le ayudan a ligar unas informaciones con otras, como es, por ejemplo, pasar del mundo real efectivo al mundo imaginado del protagonista; es un sueño lo que está

aparece en las Referencias Bibliográficas. Los números entre paréntesis después de una cita textual de Galdós, separados por una coma (por ejemplo, 83, 2), remiten el primer número a la página y el segundo a la columna donde se encuentra dicha cita.

9 «Por eso [...] esta noche, en que nuestro Genio Creador nos permite reunirnos para celebrar el primer día del año, he querido obsequiarle, trayéndole conmigo y dándole mi mano de esposa, en señal de alianza y reconciliación entre el linaje muñequil y los niños juiciosos y compasivos» $(85,2)$. 
viviendo Pacorrito, dentro de otro sueño, que es el que envuelve todo el relato. El mundo real del cuento introduce, a su vez, el submundo soñado de las aventuras del enamorado personaje, convertido ahora realmente en «un gran personaje». Son expectativas compatibles con el submundo soñado, que se introduce en el momento en que en la huida se queda dormido; pero no lo son con el real de Pacorrito al inicio del relato, del que no sabemos nada hasta el final del cuento.

En el recorrido procesual se va accediendo de un mundo a otro, pero al final no se sabe bien cómo se ha llegado al submundo de los sentimientos y lamentaciones finales de Pacorrito, que se inician en el instante mismo en que nuestro personaje afirma con aplomo: «Quiero ser muñeco» $(86,1)$, respondiendo así al deseo expreso de la dama del escaparate de renunciar a su personalidad humana, porque - como dice la dama de Migajas - «siendo distintas nuestras naturalezas, no podemos unirnos» $((86,2)$. Desde aquel momento, Pacorrito, según el narrador:

«... experimentaba ... sensaciones peregrinas. La más extraña haber perdido por completo el sentido del paladar y la noción de alimento.

... Notaba en su cuerpo una gran dureza...; su persona sonaba a porcelana... Cuando la estrechó (a su mujercita) entre sus brazos, no experimentó sensación alguna de placer ...; las mejillas las encontró heladas... Sintió palpitar su corazón como una máquina de reloj. Sus pensamientos subsistían, pero todo lo restante era miserable materia» $(87,2)$.

«Dios mío, qué frialdad, qué dureza, qué vacío, qué rigidez!

¡Vida, vida, sangre, color, pellejo!

¿Qué es esto que pasa en mí?

Todo desapareció de súbito... Se quedó solo y en oscuridad profunda. Quiso gritar y no tenía voz $(88,1)$. Quiso moverse y carecía de movimiento. Era piedad.

... Ya no me queda duda —exclamó llorando por dentro-, soy mismamente como un ladrillo» $(88,2)$.

Entonces se quedó sólo como lo estaba al principio y se vio todo de un color y de una misma materia: ¡Estoy en el escaparate!... ¡Horror!

El diagrama siguiente expresa las relaciones secuenciales entre los diferentes submundos del cuento. Las flechas que aparecen en el cruce de cada dos cuadros indican el orden de los acontecimientos, aunque, como hemos dicho más arriba, se dan una serie de entrecruzamientos entre los submundos imaginado y soñado. Las dos flechas que «rompen» los enmarques tienen que ver con la relación que hemos establecido entre el cuentista, Benito Pérez Galdós, y la ficción. 
EL NOVELISTA: Benito Pérez Galdós

Ficción fantástica inverosimil

MUNDO REAL EFECTIVO: Texto

NARRADOR

Submundo de la ironfa

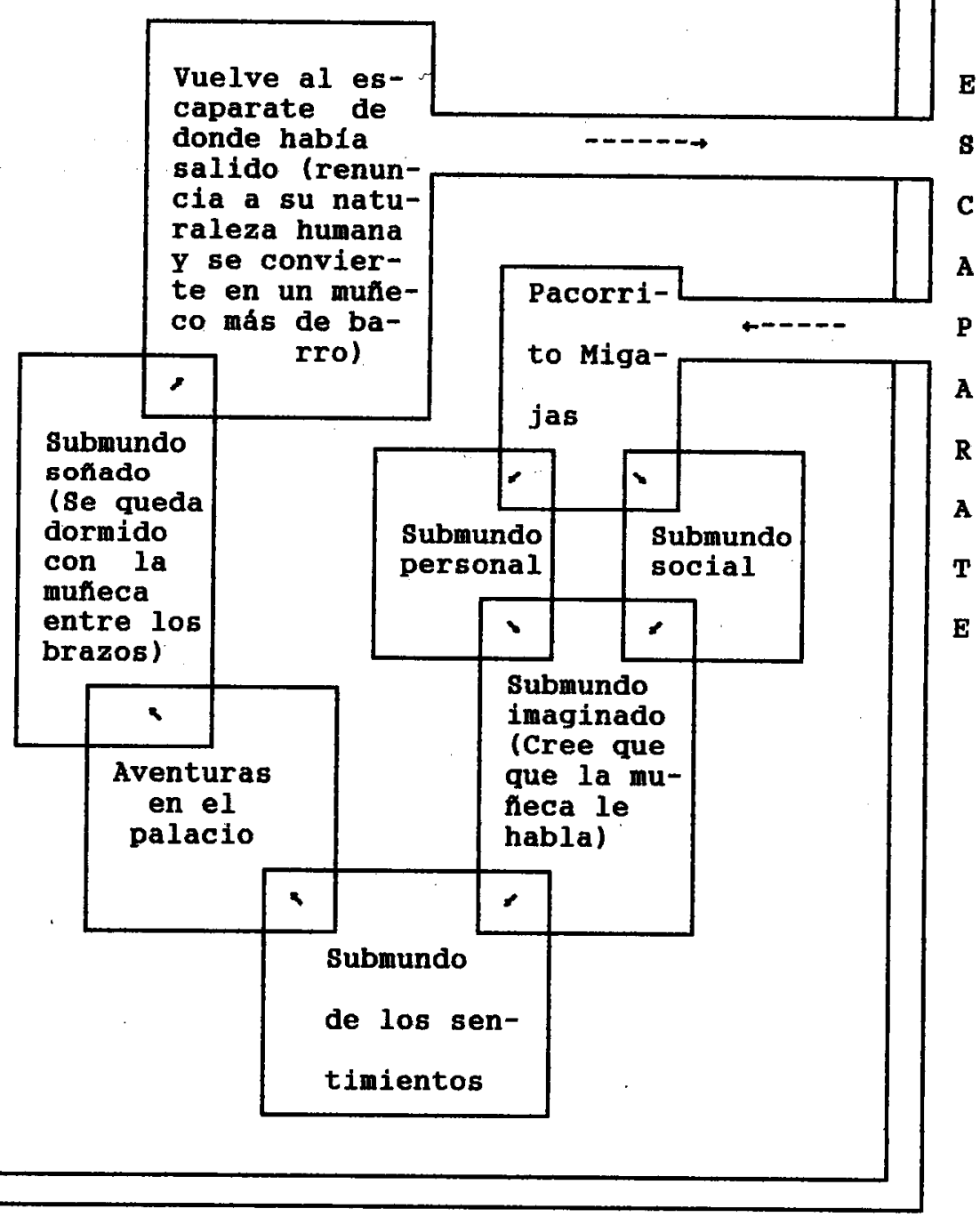




\section{INTERPRETACIÓN Y CONCLUSIONES}

5.1. El proceso de racionalización, o, lo que es lo mismo, el intento de adecuar la información a los marcos de los que disponemos (Dijk, 1983 [1978]: 209), restablece el sentido correcto del texto: se trata de un cuento. Un personaje, Migajas, protagonista de una serie de aventuras, se queda dormido y en el sueño vive otras aventuras, reales también en ese submundo. Desde ahí vuelve al mundo real auténtico, el referencial, el extratextual, si así se quiere expresar, que no es el del Pacorrito vendedor de periódicos y de fósforos, sino el de un muñeco más de barro, colocado en un escaparate y con un cartel que indica su precio en reales. Así, a través del submundo soñado, el componente onírico, que todo lo envuelve, pasa a convertirse en un mundo alternativo, donde lo sucedido es extraordinariamente real en ese mundo dado.

El entrecruzamientos de submundos, sobre todo el real efectivo y el soñado, es la causa de que el lector, en algunos momentos, se sienta algo perplejo; todos los gestos parecen pertenecer tanto al mundo real efectivo como al submundo del sueño, y las hipótesis se van sucediendo. La que modifica a la primera queda a su vez modificada al acceder a la narración el mundo del sueño, cuando Pacorrito, después de toda la aventura del palacio, en la huida, como hemos dicho, se queda dormido.

5.2. El lector del cuento La princesa y el granuja no posee la totalidad del sistema de mundos del texto hasta que no finaliza su lectura. Ahora se reconstruye el relato; ahora se interpreta; ahora se capta la realidad, que es la del sueño; y la otra, la primera, pertenece al mundo deseado, y a la vez inaccesible, de los muñecos de barro, que no es sino vivir y sentir como los humanos.

La modalidad del querer, que es el deseo (Greimas/Courtés, 1989) - podíamos haber hablado del submundo deseado- encierra a nuestro personajillo en el mundo de la fantasía, y de ahí al sueño, donde tienen lugar los acontecimientos más hermosos e inimaginables para Migajas.

El simulacro, entendido el término en el sentido de Greimas/Courtés, que es un sueño dentro de otro sueño o, mejor, de una ficción, que es la del mundo real efectivo del texto, expulsa a nuestro personaje, no a la realidad semiótica, cuya definición tiene que ver con el objeto 
construido -el texto o submundo real efectivo-, sino a la realidad real o mundo referencial, es decir, la del novelista, la de Galdós, al que muy bien podríamos imaginar delante del escaparate de una tienda de muñecos de barro. La representación de ese posible ente vivido, que es la realidad del escaparate, y su posterior plasmación en un cuento, constituyen instantes consecutivos de la corriente de la conciencia (Martínez Bonati, 1992: 173), en el supuesto de que así sucediera en el mundo referencial. En todo caso reivindicamos el derecho a imaginar que así sucediera, en efecto.

El cuento La princesa y el granuja, a nuestro juicio, como creación, constituye una dislocación del objeto real - la vida humana- a un espacio imaginario y poético. Quizás, con Martínez Bonati (1992: 176), pueda decirse que «constitutivamente es un acto de recuperación del sentido original y originario». Interpretado así puede que la ficción galdosiana sea una alegoría sobre la superioridad de la vida humana en relación a otras realidades existentes o posibles.

A este respecto es acertado recordar aquellas palabras de Aristóteles de que «la poesía dice más bien lo general», (García Yebra, 1974: 158); es decir, lo universal. De ahí que pueda afirmarse que la ficción no excluye la posibilidad de presentar verdades universales.

\section{Referencias bibliográficas}

\section{a) Libros:}

Albaladejo Mayordomo, T. (1986). Teoría de los mundos posibles y macroestructura narrativa. Alicante: Universidad de Alicante.

AlBERT GALERA, J. (1987). Estructura funcional de los «Milagros» de Berceo. Logroño: Instituto de Estudios Riojanos.

BOBES NAVES, $\mathbf{M}^{\mathrm{a}}$. del C. (1973). La semiótica como teoría lingüística. Madrid: Gredos.

COSERIU, E. (1977). El hombre y su lenguaje. Madrid: Gredos.

DIJK, T. A. VAN (1983 [1978]). La ciencia del texto. Un enfoque interdisciplinario. Barcelona-Buenos Aires: Paidós Comunicación.

Greimas, A. J. y CoURTÉs, J. (1989). Semiótica. Diccionario razonado de la teoría del lenguaje. Madrid: Gredos.

Guiraud, P. (1976, $3^{\mathrm{a}}$ reimp. [1955]). La semántica. México: Fondo de Cultura Económica. 
- (1977 [1976]). Tratado de semiótica general. Barcelona: Lumen.

HJelmSlev, L. (1974 [1943]). Prolegómenos a una teoría del lenguaje. Madrid: Gredos.

KristeVA, J. (1978). Semiótica I y Semiótica 2. Madrid: Editorial Espiral/ Fundamentos.

LyONS, J. (1975³ [1968]). Introducción en la lingüística teórica. Barcelona: Teide.

- (1983 [1981]). Lenguaje, significado y contexto. Barcelona: Paidós Comunicación.

MAlmberg, B. (1977 [1973]). Teoría de los signos. Madrid: Siglo XXI.

MARTínez BonAti, F. (1992). La ficción narrativa (Su lógica y ontología). Murcia: Universidad de Murcia.

MoRRIS, Ch. (1958 [1938]). Fundamentos de la teoría de los signos. México: Universidad Autónoma de México.

- (1962 [1946]). Signos, lenguaje y conducta. Buenos Aires: Losada.

PÉrez Galdós, B. (1977). Cuentos y teatro. Madrid: Aguilar.

PETÖFI, J. S. (1975). Vers une théorie partielle du texte. Helmut Buske Verlag Hamburg: Papiere zur Textlinguistik.

Saussure, F. (1976 ${ }^{15}$ [1916]. Curso de Lingüística General. Buenos Aires: Losada.

WEINRICH, H. (1981 [1976]). Lenguaje en textos. Madrid: Gredos.

\section{b) Volúmenes colectivos}

Albert Galera, J. (1988). «La isotopía muerte como configuradora de Bodas de sangre de García Lorca». En Lo teatral y lo cotidiano, AES (ed.), 53-67. Oviedo: Servicio de Publicaciones de la Universidad de Oviedo.

Albert GalerA, J. (1992). «Semiosis textual y superposición de mundos». En Signs of Humanity. L homme et ses signes, I, G. Delledalle (ed.) 535540. Berlín: Mouton de Gruyter.

\section{c) Artículos:}

Albaladejo, T. y García Berrio, A. (1983). «La lingüística del texto». En Introducción a la lingüística, 217-260. Madrid: Alhambra Universidad.

BARTHES, R. (19744). «Introducción al análisis estructural de los relatos». En Análisis estructural del relato. Varios Autores, 9-43. Buenos Aires: Tiempo Contemporáneo (Communications, n. ${ }^{\circ} 8$ ).

COSERIU, E. (1978). «Semántica y gramática». En Gramática, semántica, universales, 128-147. Madrid: Gredos. 